\title{
PROBLEMS OF SAFETY IN AVIATION
}

\section{PROBLEMY BEZPIECZEŃSTWA W LOTNICTWIE}

\author{
Adam Bagiński, Józef Żurek \\ Air Force Institute of Technology \\ Instytut Techniczny Wojsk Lotniczych \\ e-mail: jozef.zurek@itwl.pl
}

\begin{abstract}
The article describes the flight safety problems. It details a set of factors shaping the flight safety and activities required to maintain the requisite safety level. Attention has been paid to the need for rational safety management, including event history, risk assessment and risk cause investigation. Summary contains conclusions from the analysis of the flight safety status in transportation aviation.
\end{abstract}

Keywords: Flight safety, safety shaping, excess.

Streszczenie: W artykule dokonano opisu problemów bezpieczeństwa lotów. Wymieniono zespół czynników kształtujących bezpieczeństwo lotów i działań niezbędnych do utrzymania wymaganego poziomu bezpieczeństwa. Zwrócono uwagę na potrzebę racjonalnego zarządzania bezpieczeństwem, a w tym ewidencji zdarzeń, oceny ryzyka i badania przyczyn zagrożeń. W podsumowaniu przedstawiono wnioski $\mathrm{z}$ analizy stanu bezpieczeństwa lotów $\mathrm{w}$ lotnictwie transportowym.

Slowa kluczowe: Bezpieczeństwo lotów, kształtowanie bezpieczeństwa, nadmiary. 


\section{PROBLEMS OF SAFETY IN AVIATION}

\section{Introduction}

Transportation system safety covers two action directions, namely prevention and intervention.

As part of prevention, tasks involving safety shaping in the developed and modernised systems, and safety management for the purpose of maintaining it at the required level are realised.

Aviation system safety shaping is realised through:

- development, construction and production of aviation technique,

- designing organisation and principles of system operation (structures, procedures, competences, etc.),

- personnel and equipment operators training.

Safety management is aimed at maintaining the required safety status through the development of systems and methods of investigating into risk causes and results, in particular through:

- following human activities and technique quality,

- analysis of events (causes and results) and formulating assessments,

- designing and implementing preventive prophylaxis against undesired events, assessment of the results of the prophylaxis applied and provision of data to links shaping safety.

As part of intervention, tasks involving alleviating results of catastrophes, accidents and other undesired events are realised.

The term 'safety' is the state of absence of risk, a state of peace and certainty.

Aircraft operation safety means a state of absence of any risk related to the operation, maintenance, power supply and management of the aircraft.

Air transportation system safety is frequently treated as a property enabling realisation of air transportation in specific climatic and meteorological conditions, without aviation accidents.

Inequivalence of the definitions and interpretations of the terms implies that the emerging new scientific discipline, that being safety, features relatively poorly established basic terms, standards and measures.

Open problems still include investigations of risks to safety and the assessment of its status. 
Problemy bezpieczeństwa w lotnictwie.

Most generally, investigations may be reduced to the analysis of such factors as:

- risk of threats to safety arising in the air transportation system and its environment ;

- air transportation system and external rescue systems capability of counteracting arising threats and their results;

- interrelationships between the threat to safety and the effectiveness of prevention and alleviation of the results of the events arising.

\section{Safety - related problems analysis}

The air transportation system (ATS) being the subject matter of the analysis from the point of view of flight safety is subject to simplifications boiling down to a model comprising such subsystems as: aircraft, crew, flight management centre and ground activity assurance.

Each of the subsystems generates threats which may be caused by: external interferences (e.g. climatic and natural) and internal interferences originating from organisational and functional properties or the 'human factor', aircraft wear and aging related destruction as well as other imperfections of the system.

For the purposes of the analysis of the ATS operation errors generating threats, a simplified model created by the following system is examined: human - aircraft - surroundings (H-AC-S).

Analysing human impact on the H-AC-S system, one ought to allow for the pilot action model in the realisation of undisturbed planned mission and operation in situations involving threats to safety. The contemporary pilot is a highly specialised operator of a complex aircraft (AC) who, in an automated cabin, monitors the systems and selects the incoming information, seeks answers to arising questions, and takes decisions thus solving sequentially arising problems. The human backs up the open system steering automation. Despite application of modern technologies and automation, 'reality' surprises the pilot with unexpected circumstances, and his or her operation errors constitute significant reasons for aviation accidents.

Human as a pilot is the weakest link of the system examined, which is proven by the aviation accident statistics; also, as a crew member, device operator or service provider, he or she may make mistakes causing threats originating from:

- ignorance of a given profession (low training level or task incorporation); 
- forgetfulness resulting from the absence of procedure or activity repetitions (routine, absence of training);

- insubordination caused by the nature, lack of control or of motivation;

- absence of predispositions for a given profession (health condition, personality features).

Rational analysis of pilot errors becomes possible if we have at our disposal the training process as well as predispositions and personality features examination documentation. If the aforementioned data is located in an IT database, it may be processed and generalised conclusions improving the education and training process may be formulated. Error analysis model based on appropriately classified sequences of events distributed on the axes of flying time, training time, pilot lifetime, etc., ought to determine the risk of error occurrence and the risk change trends. In order to correctly conclude on the human impact on the flight safety, other probabilistic characteristics of random error-making processes are also required.

Beside the operational values, the aeroplane construction process also allows for the security aspect provided for in the applicable regulations and standards, current theory and designing methods, and utilises latest manufacturing technology achievements

Similarly to any other domain of human activity, also constructing and manufacturing aircrafts are not free from errors. Thus, one needs to allow for:

- hidden structure errors revealing in the operation process and endangering the flight safety;

- badly aligned diagnostic control, maintenance and renovation moments provided for in the instructions;

- operational transgressions in the form of mechanical and thermal excesses, voltage and pressure impulses, etc.

Thus, the aircraft causes threat through incorrect operation induced by:

- structure imperfection;

- failure to adjust the operation programme to the nature of wear and aging;

- failure to comply with established operation standards;

- incorrect operation procedures and technologies;

- random damaging of functional elements and systems.

The flight management system causes threat through:

- inappropriate mission preparation and delegation;

- incorrect weather diagnosis;

- interferences in radiolocation control and communication; 
Problemy bezpieczeństwa w lotnictwie.

- incorrect or incomprehensible information and decision delivery during the flight.

The environment and the ground safety system endanger the flight safety due to:

- air and ground obstacles and bird passing surprising the pilot;

- surprising changes of weather and visibility;

- incorrect consumable parts (fuels, utilities);

- incorrect airport preparation (take-off and landing routes);

- incorrectly operating airport infrastructure.

The H-AC-S system discussed features numerous excesses and safeguards enabling error correction and counteracting threats. Human, as the most complex element of the system, has great capabilities of counteracting threats and hazardous situations. In an unusual or particularly hazardous situation, only the man can act intelligently, quickly and reasonably.

A specific factor affecting the man is stress, especially stress involving awareness of shortage of time while counteracting a threat. Insignificant shortage of time mobilises human activity, reduces error probability and improves the intensity of correct operation. The mobilising process lasts until a certain level of consciousness is achieved.

When time at hand is twice as short as the time required, there occurs the incremental demobilisation of the operator and all the parameters of errorfree operation aggravate. Human as an operator still has the subconscious sphere, which also affects error elimination and thus the flight safety.

Flight safety shaping is the direct or indirect human impact on the air transportation system. Praxeological elements of flight safety are in various stages of aviation technique development and utilisation and preparation of the aircrew, engineering and aviation personnel and flight securing personnel.

Based on long term experience resulting from aircraft operation, often 'blood-written', certain general praxeological principles may be formulated, observance of which is of significant importance to the flight safety. These include [3]:

1) Principle applicable to the pilot: 'I do not know, I cannot, I feel bad, so I do not get into the aircraft cabin intending to fly'.

2) Principle applicable to the technician: 'I do not know, I cannot, so I first ask and learn, and only then do I do it'.

3) Realisation of maintenance activities and repairs in strict accordance with established technologies.

4) Observance of the regulations.

5) Explanation of the reasons for all the damages and inefficiencies. 
6) Executing works only with operational and legalised tools and control instruments.

Certainly, the aforementioned principles do not constitute a comprehensive list. There are numerous specific principles characteristic of only a specific type of aviation or aircraft, or even aviation and engineering specialisation. Aircraft may be treated as a system consisting of a fuselage, driving system, steering system, accessories, onboard equipment and weapons in the case of military aeroplanes and helicopters.

Almost every functional assembly and system of an aircraft has an excess reliability structure, which means that the arising damages to certain elements do not cause the aircraft inoperation and do not endanger the flight safety.

We distinguish the following excesses:

- Structural excess. Involves application of primary systems and elements executing the functions assigned, and back-up systems and elements activated in the event of the primary elements becoming damaged. The structural excess system can be represented by the aeroplane undercarriage deployment system consisting of the primary and emergency (back-up) subsystems. The back-up system is utilised in the event of the primary system failure. Other examples of the structural excess are the back-up devices on passenger planes, used to replace damaged devices during the flight.

- Functional excess. Involves the element executing its strictly determined function, yet in specific situations it may execute additional functions instead of a damaged element. This may be explained on the example of aeroplane undercarriage and sheathing. The aeroplane undercarriage function is to ensure aeroplane taking off and landing, and the aeroplane sheathing is to ensure appropriate aerodynamic form of the aeroplane. In the event of undercarriage damaging, the aeroplane sheathing substitutionally performs the undercarriage functions, enabling emergency landing.

- Time excess. Boils down to system element interaction, in particular human - technical system interaction. This may be exemplified by backup power sources, ability to start the engine in the air (time excess depends on flight altitude) etc.

- Information excess. Involves doubling information (e.g. light and mechanical aeroplane undercarriage deployment signalisation). Systems provided with such elements are described as systems with information excess. 
- Parametric excess. Features of the system must correspond with specified requirements regarding the range of their variability. Important features (rates) of the system are called parameters. Engine power may be an exemplary parameter. The constructor determines the engine power range required to ensure aircraft flight. Usually, in twin-engine aeroplanes, a single engine power enables aeroplane flight (with limitations). Despite damaging of one engine, in many cases it is possible for the aeroplane to land safely. Similarly, this can be said about a multicylinder combustion engine. The power of such an engine is within the admissible range, where at least $m$ of $n$ cylinders are operational.

- Resistance excess. The so-called safety coefficient is included in the structure designing process. The safety coefficient is determined both for mechanical structures and electrical and pneumatic equipment. Such systems are classified as systems featuring resistance excess.

The aircraft usually features all the forms of excess jointly, and they increase both active and passive safety. Active safety depends on excesses securing correct aircraft operation, whereas passive safety is aimed at alleviating the results of aviation accidents. Aircraft safety depends on the implemented technical and organisational undertakings in order to reduce the level of danger both during the accident prevention phase and the accident results alleviation phase. These undertakings include:

- reducing the possibility of occurrence of external factors initialising the threat (utilisation beyond the atmospheric danger zone);

- reducing the possibility of occurrence of internal factors initialising the threat (utilisation of highly reliable elements in the construction of an aircraft);

- reducing the aircraft sensitivity to the impact of external initialising factors (thermal sheathing, systems against atmospheric discharges, air conditioning);

- reducing the aircraft sensitivity to the impact of external initialising factors (aircraft reliability and safety excess structure);

- reducing the risk of aviation accident and alleviating its results due to undesired progress of a hazardous situation; in these circumstances, an important role is played by the securing systems and rescue systems (fire installations and systems, systems starting the engine in the air, systems enabling to leave the pilot's cabin in the air, and others).

Beside the aforementioned devices, aimed at preventing threat occurrence, aircraft feature systems ensuring safety related to the operation of the aircraft. These include the following systems:

- systems reducing the rake angle; 
- systems reducing load;

- systems reducing the flight altitude.

The aforementioned securing devices are related to the limitations occurring in the operation process. Incorporation of these devices takes place upon exceeding the flight parameters threshold values. Such situations take place during realisation of certain tasks assumed.

Operational studies of the safety systems face significant difficulties. This results from limited possibilities of collecting operational data. Ensuring sufficient reliability of the safety indicators assessment is most difficult, hence conducting model studies of the safety system plays an important role. Model parameters are determined based on experience and then system reliability and safety indicators are estimated. The modelling process begins with the development of a model functional from the point of view of reliability and safety. Developed mathematical models and aircraft emergency state generation rules with the application of the following methods: damage tree, Monte Carlo and others, make it possible to assess the risk of damages and incidents endangering safety, and other undesired events.

The increase in the complexity of the aircraft structure is followed by the increasing elements damage intensity. The damages arise due to aging and wear related process as well as due to human interference involving too frequent disassemblies in order to control the condition and maintain the aircraft. A rational way out of this situation is the application of automatic condition control with the use of system operation parameters recorders. The recorders continuously or discreetly monitor the technical condition, record overloads and enable determination of the wear trajectory or the remaining operation time. Despite the increased aircraft elements damage intensity, the structure safety increases. The reason for this phenomenon is the rational excess and safeguard consumption. The history of aviation development initially observed a close dependence between the aircraft safety and reliability which, as aviation developed, clearly loosened. The coefficient of correlation between structure reliability and safety tends to decrease from a value close to one at the beginning of aviation development to a value close to zero in contemporary structures.

\section{Summary}

Based on the conducted analysis of the status of the flight safety in transportation aviation, the following conclusions regarding the transportation aviation system may be formulated: 
1. Despite dynamic growth of the flying time and of the number of aviation operations in air transportation, the flight safety remains at a high level.

2. In recent years, the number of emergency situations related to the unreliability of the aviation technique has decidedly decreased, whereas the number of risks associated with air traffic has increased.

3. The results of the studies conducted confirm the fact that similarly to global aviation, the most aviation events occur at airports and in the direct vicinity of them during take-offs, approaching to land, and landing.

4. Current threats to the flight safety are directly related to the increase of the number of air operations and in particular regard the absence of appropriate separation at airports and in their area.

5. Air traffic threats are mainly related to a great number of air operations at the same time and operational offences of the air services with respect to cooperation between individual management posts and aircrews as well as the lack of abilities to solve conflict situations.

6. In air transportation, threats related to the operation of aircrews resulting mainly from the absence of appropriate cooperation within the crew and with the air traffic services are still present.

7. Factors having significant impact on the flight safety are environmental factors, in particular atmospheric factors which affect, among others, taxi strip and runway condition, landing conditions and turbulence during the flight.

8. Great impact on the occurrence of situations endangering the flight safety results from the absence of complete information on incidents and other aviation events, which prevents their examination and development of appropriate prophylactic undertakings. The reason for this state of affairs is the absence of appropriate Safety Management System and 'Just Culture' programmes.

9. Amendments to the aviations law and executive regulations related to the law prevent a fully reliable comparison of the air transportation flight safety in individual years.

Bibliography:

1. D. Wagner: Niezawodność statków powietrznych realizujacych zadania ratownictwa morskiego ze szczególnym uwzględnieniem awioniki, Prace Naukowe ITWL, Z-6, Warsaw 1999. 
2. J. Jażwiński, K. Ważyńska-Fiok: Bezpieczeństwo Systemów, Wydawnictwo Naukowe PWN, Warsaw 1993.

3. J. Jaźwiński, J. Borgoń: Niezawodność eksploatacyjna i bezpieczeństwo lotów, Wydawnictwa Komunikacji i Łączności, Warsaw 1989.

4. M. Urbański, W. Wołkowski: Badanie i predykcja wskaźników bezpieczeństwa lotów w Lotnictwie Sit Zbrojnych RP, Wydawnictwo ITWL, Warsaw 1998.

5. J. Żurek: 'Wspomaganie informatyczne $w$ sterowaniu procesem eksploatacji techniki wojskowej', Informator II Konferencji PROBLEMY EKSPLOATACJI TECHNIKI WOJSKOWEJ, Wydawnictwo ITWL, Warsaw 2000.

6. J. Borgoń, J. Jaźwiński, S. Klimaszewski, Z. Żmudziński, J. Żurek: Symulacyjne metody badania bezpieczeństwa lotów, Wydawnictwo Naukowe ASKON, Warsaw 1998.

7. J. Żurek Żywotność śmigłowców Wydawnictwo - Biblioteka Problemów Eksploatacji Radom, 2006.

8. Żurek Józef: 'Wspomaganie informatyczne $w$ sterowaniu procesem eksploatacji techniki wojskowej', Systemy Logistyczne Wojsk, Issue 31. Instytut Logistyki, Systemów Dowodzenia i Wsparcia Wojskowej Akademii Technicznej. Warsaw 2006, pp. 345-360. 


\section{PROBLEMY BEZPIECZEŃSTWA W LOTNICTWIE}

\section{Wstęp}

Bezpieczeństwo systemów transportowych obejmuje dwa kierunki działań takie jak, prewencję i interwencję.

W ramach prewencji realizuje się zadania polegające na kształtowaniu bezpieczeństwa $\mathrm{w}$ budowanych $\mathrm{i}$ modernizowanych systemach oraz zarządzanie bezpieczeństwem w celu utrzymania go na wymaganym poziomie.

Kształtowanie bezpieczeństwa systemów lotniczych realizuje się poprzez:

- rozwój, konstruowanie i wytwarzanie techniki lotniczej,

- projektowanie organizacji i zasad działania systemów (struktur,

- procedur, kompetencji, itp.),

- szkolenie kadr i operatorów sprzętu.

Zarządzanie bezpieczeństwem ma na celu utrzymanie wymaganego stanu bezpieczeństwa poprzez tworzenie systemów i metod badania przyczyn oraz skutków zagrożeń, a w szczególności poprzez:

- śledzenie działań ludzi i jakości techniki,

- analiza zdarzeń (przyczyn, skutków) i formułowanie ocen,

- projektowanie i wdrażanie profilaktyki zapobiegawczej niepożądanym zdarzeniom, ocena skutków stosowanej profilaktyki i dostarczanie danych do ogniw kształtujących bezpieczeństwo.

W ramach interwencji realizuje się zadania polegające na łagodzeniu skutków katastrof, wypadków i innych niepożądanych zdarzeń.

Pojęcie „bezpieczeństwo" to stan braku zagrożenia, stan spokoju i pewności.

Bezpieczeństwo eksploatacji statków powietrznych oznacza stan braku zagrożenia związanego z użytkowaniem, obsługa, zasilaniem i zarządzaniem statkiem powietrznym.

Bezpieczeństwo lotniczego systemu transportowego traktuje się często jako właściwość, umożliwiającą realizację przewozów lotniczych w danych warunkach klimatyczno-meteorologicznych, bez wypadków lotniczych.

Niejednoznaczność definicji i interpretacji pojęć świadczy, że tworząca się nowa dyscyplina naukowa, jaką jest bezpieczeństwo, posiada stosunkowo słabo ugruntowane podstawowe określenia, normy i miary. 
Otwartymi problemami pozostają też badania zagrożeń bezpieczeństwa i ocena jego stanu.

Badania najogólniej można sprowadzić do analizy czynników takich jak:

- ryzyko zagrożeń bezpieczeństwa powstałe w lotniczym systemie transportowym i jego otoczeniu;

- możliwość przeciwdziałania występującym zagrożeniom i ich skutkom przez lotniczy system transportowy oraz przez zewnętrzne systemy ratownicze;

- wzajemne relacje występujące między zagrożeniem bezpieczeństwa a skutecznością przeciwdziałania i skutecznością łagodzenia skutków zaistniałych zdarzeń.

\section{Analiza problemów bezpieczeństwa}

Lotniczy system transportowy (LST) będący przedmiotem analizy z punktu widzenia bezpieczeństwa lotów podlega uproszczeniom sprowadzającym się do modelu zawierającego podsystemy takie jak: statek powietrzny, załoga, ośrodek kierowania lotami i naziemnego zabezpieczenia działań.

Każdy z wymienionych podsystemów jest generatorem zagrożeń, których przyczyną mogą być: zakłócenia zewnętrzne (np. klimatycznoprzyrodnicze) i zakłócenia wewnętrzne pochodzące od właściwości organizacyjnych, funkcjonalnych, „,czynnika ludzkiego” oraz destrukcji zużyciowo-starzeniowej statku powietrznego a także innych niedoskonałości systemu.

Dla potrzeb analizy błędów w działaniu LST generujących zagrożenia rozpatruje się uproszczony model jaki tworzy układ: człowiek - statek powietrzny - otoczenie (C-SP-O).

Analizując wpływ człowieka na bezpieczeństwo układu C-SP-O należy uwzględniać model działania pilota $\mathrm{w}$ realizacji niezakłóconej zaplanowanej misji oraz działania w sytuacjach zagrożenia bezpieczeństwa. Współczesny pilot to wysoce wyspecjalizowany operator złożonego statku powietrznego (SP), który w zautomatyzowanej kabinie nadzoruje systemy i prowadzi selekcje napływających informacji, poszukuje odpowiedzi na pojawiające się pytania oraz podejmuje decyzje rozwiązując sekwencyjnie pojawiające się problemy. Stanowi rezerwę dla automatyki realizujących sterowanie w układzie otwartym. Mimo zastosowań nowoczesnej techniki i automatyki, „rzeczywistość” zaskakuje pilota nieprzewidzianymi okolicznościami a jego błędy w działaniu stanowią istotne przyczyny wypadków lotniczych.

Człowiek jako pilot stanowi najsłabsze ogniwo w rozpatrywanym systemie, o czym świadczą statystyki wypadków lotniczych również jako członek 
załogi, operator urządzenia lub wykonujący obsługę może popełniać błędy powodujące zagrożenia, które pochodzą od:

- niewiedzy w danej profesji (niski poziom wyszkolenia lub niezrozumienie zadania);

- niepamięci wynikającej z braku powtórzeń procedur lub czynności (rutyna, brak treningu);

- niesubordynacji spowodowanej charakterem, brakiem kontroli lub motywacji;

- braku predyspozycji do danego zawodu (stan zdrowia, cechy osobowości).

Racjonalna analiza błędów pilota staje się możliwa jeżeli dysponujemy dokumentacją procesu szkolenia i badania predyspozycji oraz cech osobowości. Jeżeli wymienione dane znajdują się w bazie informatycznej to można je przetwarzać i formułować uogólnione wnioski doskonalące proces szkolenia oraz treningu. Model analizy błędów oparty na przetwarzaniu odpowiednio poklasyfikowanych ciaggów zdarzeń rozmieszczonych na osiach czasu nalotu, czasu treningu na symulatorach, czasu życia pilota itp. powinien wyznaczać ryzyko ich wystapienia oraz tendencję zmian tego ryzyka. Do poprawnego wnioskowania o wpływie człowieka na bezpieczeństwo lotów niezbędne są również inne charakterystyki probabilistyczne losowych procesów popełniania błędów.

W procesie konstruowania samolotu obok walorów użytkowych uwzględnia się aspekt bezpieczeństwa wyrażony $\mathrm{w}$ obowiązujących przepisach i normach, w aktualnie istniejącej teorii oraz w metodach projektowania, a także wykorzystuje się najnowsze zdobycze technologii wytwarzania.

Podobnie jak każda dziedzina ludzkiej działalności również konstruowanie i wytwarzanie statków powietrznych nie jest wolne od błędów. Należy się więc liczyć z:

- ukrytymi błędami konstrukcji objawiającymi się $\mathrm{W}$ procesie eksploatacji i zagrażającymi bezpieczeństwu lotów;

- źle dopasowanymi momentami kontroli diagnostycznych, obsług i odnów zawartych w instrukcjach;

- przekroczeniami eksploatacyjnymi w postaci przeciążeń mechanicznych, cieplnych, impulsów napięć ciśnień itp.

Statek powietrzny powoduje więc zagrożenie przez niewłaściwe funkcjonowanie wywołane:

- niedoskonałością konstrukcji;

- niedopasowaniem programu eksploatacji do natury zużycia i starzenia; 
- nieprzestrzeganiem ustalonych norm eksploatacyjnych;

- błędnymi procedurami i technologiami obsługi;

- losowymi uszkodzeniami elementów i układów funkcjonalnych.

System kierowania lotami powoduje zagrożenie poprzez:

- nieodpowiednie przygotowanie i przekazanie misji;

- błędne rozpoznanie pogody;

- zakłócenia w kontroli radiolokacyjnej i łączności;

- błędne lub niezrozumiałe przekazywanie informacji oraz decyzji w czasie lotu.

Środowisko i system naziemnego zabezpieczenia działań zagraża bezpieczeństwu lotów z powodu:

- zaskakujących pilota przeszkód powietrznych, terenowych i przelotu ptaków;

- zaskakujących zmian pogody i widoczności;

- niewłaściwych materiałów eksploatacyjnych (paliwa, mediów);

- niewłaściwie przygotowanego lotniska (drogi startu i lądowania);

- niewłaściwie funkcjonującej infrastruktury lotniskowej.

Omawiany układ C-SP-O posiada szereg nadmiarów i zabezpieczeń umożliwiających naprawianie błędów i przeciwdziałanie zagrożeniom. Człowiek jako najbardziej złożony element w układzie posiada ogromne możliwości przeciwdziałania zagrożeniom i sytuacjom niebezpiecznym. W nietypowej lub szczególnie niebezpiecznej sytuacji tylko człowiek potrafi działać inteligentnie, szybko i roztropnie.

Specyficznym czynnikiem działającym na człowieka jest stres a szczególnie stres polegający na świadomości deficytu czasu podczas przeciwdziałania zagrożeniu. Niewielki deficyt czasu wpływa mobilizująco na działanie człowieka, zmniejsza prawdopodobieństwo popełnienia błędu i poprawia intensywność poprawnego działania. Proces mobilizujący trwa do osiagnięcia pewnego progu w świadomości.

Gdy czas dysponowany jest dwukrotnie krótszy od czasu niezbędnego, to następuje skokowa demobilizacja operatora i wszystkie parametry bezbłędnego działania pogarszają się. Człowiek jako operator posiada jeszcze sferę podświadomości, która także wpływa na eliminację błędów, a co za tym idzie na bezpieczeństwo lotów.

Kształtowanie bezpieczeństwa lotów jest bezpośrednim lub pośrednim oddziaływaniem człowieka na lotniczy system transportowy. Prakseologiczne pierwiastki bezpieczeństwa lotów tkwią w różnych etapach 
tworzenia i eksploatacji techniki lotniczej oraz przygotowania załóg lotniczych, personelu inżynieryjno-lotniczego i personelu ubezpieczającego loty.

$\mathrm{Na}$ podstawie wieloletnich doświadczeń wynikających $\mathrm{z}$ eksploatacji statków powietrznych, często ,pisanych krwią”, można sformułować pewne ogólne zasady prakseologiczne, których przestrzeganie w działaniu posiada istotne znaczenie dla bezpieczeństwa lotów. Oto one [3]:

1) Zasada obowiązująca pilota: „Nie wiem, nie umiem, źle się czuję, a więc nie wsiadam do kabiny statku powietrznego z zamiarem lotu".

2) Zasada obowiązująca technika: „Nie wiem, nie umiem, a więc najpierw pytam, uczę się, a dopiero po tym wykonuje".

3) Realizacja czynności obsługowych i napraw ściśle według ustalonych technologii.

4) Przestrzeganie przepisów.

5) Wyjaśnianie przyczyn wszystkich uszkodzeń i niesprawności.

6) Prowadzenie prac tylko sprawnymi i zalegalizowanymi narzędziami i przyrządami kontrolnymi.

Wymienione zasady z pewnością nie wyczerpują kompletnej listy. Istnieje wiele specyficznych zasad charakterystycznych tylko dla konkretnego typu rodzaju lotnictwa lub statku powietrznego, a nawet specjalności lotniczotechnicznej.

Statek powietrzny można potraktować jako system składający się z płatowca, zespołu napędowego układu sterowania, osprzętu, wyposażenia pokładowego i uzbrojenia $\mathrm{W}$ przypadku samolotów i śmigłowców wojskowych.

Prawie wszystkie zespoły i układy funkcjonalne statku powietrznego posiadają nadmiarową strukturę niezawodnościową co oznacza, że występujące uszkodzenia niektórych elementów nie powodują niezdatności statku i nie zagrażają bezpieczeństwu lotów.

Wyróżniamy następujące nadmiary:

- Nadmiar strukturalny. Polega na zastosowaniu układów i elementów podstawowych realizujących przypisane funkcje oraz układów i elementów rezerwowych włączających się do pracy w przypadku uszkodzenia elementów podstawowych. Reprezentantem systemu z nadmiarem strukturalnym jest system wypuszczania podwozia na samolocie, składający się $\mathrm{z}$ podsystemu podstawowego i awaryjnego (rezerwowego). Układ rezerwowy wykorzystuje się w przypadku, gdy zawiedzie układ podstawowy. Innymi przykładami nadmiaru strukturalnego są zapasowe urządzenia na pokładzie samolotów pasażerskich, które służą do wymiany w locie urządzeń uszkodzonych. 
- Nadmiar funkcjonalny. Polega na tym, że element wykonuje swoją ściśle określoną funkcję, jednakże $\mathrm{w}$ określonych sytuacjach może on pełnić dodatkową funkcję zamiast elementu uszkodzonego. Można to wyjaśnić na przykładzie podwozia i pokrycia samolotu. Funkcją podwozia samolotu jest zapewnienie startu i lądowania samolotu, a pokrycia samolotu - zapewnienie odpowiednich kształtów aerodynamicznych samolotu. $\mathrm{W}$ razie uszkodzenia podwozia pokrycie samolotu spełnia zastępczo funkcję podwozia, umożliwiając awaryjne lądowanie samolotu.

- Nadmiar czasowy. Sprowadza się do współdziałania elementów systemu, a w szczególności do współdziałania człowieka z systemem technicznym. Przykładem moga tu być rezerwowe źródła zasilania, możliwość rozruchu silnika $\mathrm{w}$ powietrzu (nadmiar czasu zależy od wysokości lotu) itp.

- Nadmiar informacyjny. Polega na zdwojeniu (dublowaniu) informacji (np. świetlna i mechaniczna sygnalizacja wypuszczania podwozia samolotu). Systemy wyposażone w takie elementy określa się jako systemy z nadmiarem informacyjnym.

- Nadmiar parametryczny. Cechy systemów muszą odpowiadać określonym wymaganiom dotyczącym zakresu ich zmienności. Istotne cechy (wielkości) systemu noszą nazwę parametrów. Przykładem parametru jest moc silnika. Konstruktor określa zakres mocy silnika niezbędnej do zapewnienia lotu statku powietrznego. Zazwyczaj w samolotach dwusilnikowych moc pojedynczego silnika umożliwia lot samolotu ( $\mathrm{z}$ ograniczeniami). Pomimo uszkodzenia jednego silnika W wielu przypadkach istnieje możliwość bezpiecznego lądowania samolotu. Podobnie można powiedzieć o wielocylindrowym silniku spalinowym. Moc takiego silnika znajduje się $\mathrm{W}$ dopuszczalnym przedziale, gdy co najmniej $m$ z $n$ cylindrów jest w stanie zdatności.

- Nadmiar wytrzymalości. W procesie projektowania konstrukcji wprowadza się tak zwany współczynnik bezpieczeństwa. Współczynnik bezpieczeństwa ustala się zarówno dla konstrukcji mechanicznych, jak też dla urządzeń elektrycznych i pneumatycznych. Systemy takie określa się, jako mające nadmiar wytrzymałości.

$\mathrm{Na}$ SP występują z reguły wszystkie formy nadmiaru łącznie i zwiększają one zarówno bezpieczeństwo czynne jak i bierne. Bezpieczeństwo czynne uzależnione jest od nadmiarów zabezpieczających poprawne funkcjonowanie SP a bezpieczeństwo bierne ma na celu złagodzenie skutków wypadków lotniczych. Bezpieczeństwo SP zależy od wprowadzanych przedsięwzięć technicznych i organizacyjnych $\mathrm{w}$ celu 
zmniejszenia stopnia zagrożenia zarówno $\mathrm{w}$ fazie zapobiegania rozwojowi wypadku jak i w fazie łagodzenia jego skutków. Do przedsięwzięć tych należą:

- ograniczenia możliwości występowania czynników zewnętrznych inicjujących zagrożenie (użytkowanie poza strefą zagrożenia atmosferycznego);

- ograniczenia możliwości występowania czynników wewnętrznych inicjujących zagrożenie ( wykorzystanie do budowy statku powietrznego elementów o dużej niezawodności);

- ograniczenia wrażliwości statku powietrznego na oddziaływanie zewnętrznych czynników inicjujących (osłony termiczne, instalacje przeciw wyładowaniom atmosferycznym, klimatyzacja);

- ograniczenia wrażliwości statku powietrznego na oddziaływanie wewnętrznych czynników inicjujących (nadmiarowa struktura niezawodności i bezpieczeństwa statku powietrznego);

- zmniejszenia ryzyka wystapienia wypadku lotniczego i złagodzenia jego skutków w wyniku niepożądanego rozwoju sytuacji niebezpiecznej; w tych okolicznościach istotną rolę odgrywają układy zabezpieczające oraz systemy ratownicze (instalacje i systemy przeciwpożarowe, instalacje uruchamiania silnika w powietrzu, system opuszczania kabiny pilota w powietrzu i inne).

Oprócz wymienionych urządzeń, mających na celu przeciwdziałanie wystąpieniu zagrożenia, istnieją na statkach powietrznych systemy zapewniające bezpieczeństwo związane z użytkowaniem statku powietrznego. Należą do nich układy:

- ograniczające kąt natarcia;

- ograniczające obciążenie prostopadłe;

- ograniczające wysokość lotu.

Wymienione urządzenia zabezpieczające są związane $\mathrm{z}$ ograniczeniami występującymi w procesie użytkowania. Włączenie tych urządzeń następuje $\mathrm{z}$ chwilą przekroczenia granicznych wartości parametrów lotu. Sytuacja taka występuje przy realizacji niektórych złożonych zadań.

Badania eksploatacyjne systemów bezpieczeństwa napotykają duże trudności. Wynika to $\mathrm{z}$ ograniczonych możliwości zbierania danych eksploatacyjnych. Zapewnienie dostatecznej wiarygodności oceny wskaźników bezpieczeństwa jest bardzo trudne, dlatego istotną rolę odgrywa prowadzenie modelowych badań systemu bezpieczeństwa. Wyznacza się na podstawie doświadczenia parametry modelu, a następnie szacuje wskaźniki niezawodności i bezpieczeństwa systemu. Proces modelowania rozpoczyna się od tworzenia modelu funkcjonalnego z punktu 
widzenia niezawodności i bezpieczeństwa. Opracowane modele matematyczne i zasady generowania stanów awaryjnych statku powietrznego z wykorzystaniem metod: drzewa uszkodzeń, Monte Carlo i innych pozwalają oceniać ryzyko uszkodzeń incydentów zagrażających bezpieczeństwu i innych niepożąalanych zdarzeń.

Ze wzrostem złożoności konstrukcji SP rośnie intensywność uszkodzeń elementów. Uszkodzenia te powstają na skutek procesów starzeniowozużyciowych oraz $\mathrm{z}$ przyczyn ingerencji człowieka przez zbyt częste demontaże w celu kontroli stanu i obsługi konserwacyjnej. Racjonalnym wyjściem $\mathrm{z}$ tej sytuacji jest zastosowanie automatycznej kontroli stanu z wykorzystaniem rejestratorów parametrów pracy systemów. Rejestratory te monitorują $\mathrm{w}$ sposób ciagły lub dyskretny stan techniczny, rejestruja przeciążenia i umożliwiają wyznaczenie trajektorii zużycia lub pozostałości zasobu pracy. Mimo wzrostu intensywności uszkodzeń elementów SP bezpieczeństwo konstrukcji wzrasta. Przyczyną tego zjawiska jest racjonalne zużycie nadmiarów i zabezpieczeń. W historii rozwoju lotnictwa zaobserwowana początkowo ścisłą zależność bezpieczeństwa i niezawodności SP, która w miarę rozwoju lotnictwa wyraźnie się rozluźnia. Współczynnik korelacji między niezawodnością a bezpieczeństwem konstrukcji ma tendencję malejącą od wartości bliskiej jedności w początkach rozwoju lotnictwa do wartości bliskiej zeru w konstrukcjach współczesnych.

\section{Podsumowanie}

$\mathrm{Na}$ podstawie przeprowadzonej analizy stanu bezpieczeństwa lotów w lotnictwie transportowym, w zespole transportu lotniczego można sprecyzować następujące wnioski:

1) Pomimo dynamicznego wzrostu nalotu i liczby operacji lotniczych $\mathrm{w}$ transporcie lotniczym stan bezpieczeństwa lotów utrzymuje się na wysokim poziomie.

2) W ostatnich latach zdecydowanie zmniejszyła się liczba sytuacji awaryjnych związanych $\mathrm{z}$ zawodnością techniki lotniczej wzrosła natomiast liczba zagrożeń związanych z ruchem lotniczym.

3) Wyniki prowadzonych badań potwierdzają fakt, że podobnie jak w lotnictwie światowym najwięcej zdarzeń lotniczych występuje na lotniskach i w bezpośredniej ich bliskości w czasie startów, podejścia do lądowania i lądowania. 
4) Aktualne zagrożenia bezpieczeństwa lotów związane są bezpośrednio ze wzrostem liczby operacji powietrznych i dotyczą w szczególności braku odpowiedniej separacji na lotniskach i w ich rejonie.

5) Zagrożenia $w$ ruchu lotniczym związane są głównie $z$ dużą liczbą operacji lotniczych w tym samym czasie i uchybieniami działania służb ruchu lotniczego w zakresie współdziałania pomiędzy poszczególnymi stanowiskami kierowania i załogami lotniczymi oraz brakiem umiejętności rozwiązywania sytuacji konfliktowych.

6) W transporcie lotniczym ciagle aktualne są zagrożenia związane z działaniem załóg lotniczych wynikające głównie z braku właściwej współpracy w załodze i z służbami ruchu lotniczego.

7) Czynnikami, które mają istotny wpływ na stan bezpieczeństwa lotów są czynniki środowiskowe, w tym szczególnie atmosferyczne, które mają wpływ między innymi na stan dróg kołowania i dróg startowych, warunki lądowania oraz turbulencję w czasie lotu.

8) Duży wpływ na powstawanie sytuacji zagrażających bezpieczeństwu lotów wynika $\mathrm{z}$ braku pełnej informacji o incydentach $\mathrm{i}$ innych zdarzeniach lotniczych co uniemożliwia ich badanie i opracowywanie odpowiednich przedsięwzięć profilaktycznych. Przyczyną takiego stanu jest brak odpowiednich programów Safety Managament System i „Just Culture".

9) Zmiany w prawie lotniczym i przepisach wykonawczych związanych $\mathrm{z}$ tą ustawą nie pozwalają przeprowadzić w pełni wiarygodnego porównania stanu bezpieczeństwa lotów w transporcie lotniczym w poszczególnych latach.

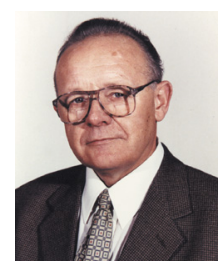

Dr. Józef Żurek, professor at Air Force Institute of Technology in Warsaw. Specialisation: mechanical engineering and machine operation/maintenance, transport, systems safety and reliability 
